\title{
Changing locus of innovation: a micro-process approach on the dynamics of proximity
}

Tanner, Anne Nygaard

Published in:

European Planning Studies

Link to article, DOI:

10.1080/09654313.2018.1529143

Publication date:

2018

Document Version

Peer reviewed version

Link back to DTU Orbit

Citation (APA):

Tanner, A. N. (2018). Changing locus of innovation: a micro-process approach on the dynamics of proximity. European Planning Studies, 26(12), 2304-2322. https://doi.org/10.1080/09654313.2018.1529143

\section{General rights}

Copyright and moral rights for the publications made accessible in the public portal are retained by the authors and/or other copyright owners and it is a condition of accessing publications that users recognise and abide by the legal requirements associated with these rights.

- Users may download and print one copy of any publication from the public portal for the purpose of private study or research.

- You may not further distribute the material or use it for any profit-making activity or commercial gain

- You may freely distribute the URL identifying the publication in the public portal

If you believe that this document breaches copyright please contact us providing details, and we will remove access to the work immediately and investigate your claim 


\title{
Changing Locus of Innovation: A Micro- Process Approach on the Dynamics of Proximity
}

Anne Nygaard Tanner, Assistant Professor.

Technical University of Denmark, Department of Management Engineering, Address:

Diplomvej 372, DK-2800 Lyngby, Denmark and CIRCLE (Centre for Innovation, Research and Competence in the Learning Economy), Lund University, Address: Sölvegatan 16, Box 118, Lund, Sweden

Email:anny@dtu.dk; anne.tanner@circle.lu.se

Phone: (+45) 60774112

ORCID ID: orcid.org/0000-0002-3145-908X

This is an Accepted Manuscript of an article published by Taylor \& Francis in European Planning Studies on October 5 2018, available online:

https://doi.org/10.1080/09654313.2018.1529143.

\begin{abstract}
:
The literature on the geography of innovation suffers from a lack of attention to temporal aspects of proximity in innovation processes. Consequently, an emerging literature on knowledge creation processes has appeared to address this shortcoming. This paper adopts this perspective and develops an integrated framework for understanding knowledge creation and proximity dynamics across phases of the innovation process (idea generation, problemsolving and implementation). Geographical proximity plays a role in all stages of the innovation process, but its form varies. Three innovation biographies from the Danish wind power industry serve as principal examples of this integrated framework. It is demonstrated that innovation processes can be multilocational, meaning innovative activities are stretched in space and may take place at multiple sites.
\end{abstract}

Keywords: multilocational innovation processes, industry-specific knowledge, dynamics of proximity, wind power industry, innovation biography 


\section{Introduction}

The literature on the geography of innovation experience in these years a shift in focus from the meso-level to micro-level processes (Butzin \& Widmaier, 2016; Davids \& Frenken, 2017; Ibert, Hautala, \& Jauhiainen, 2015; Ibert \& Müller, 2015; Rusten \& Overå, 2014; Strambach \& Klement, 2012). This trend places the process of knowledge creation in the centre and explores its spatiotemporal configurations as they unfold throughout the innovation process. The micro-level approach is a means to address the shortcomings of previous perspectives of localized learning processes, which have been predominantly studied through various knowledge-based theories of spatial clustering (Maskell \& Malmberg, 1999; Porter, 1990) and have been criticized for providing static perspectives on spatial knowledge dynamics.

Consequently, a dynamic micro-level approach has developed wherein the analytical focal point is how ideas, entities or people change over time and through the way these are organized and interlinked in space. The aims are to uncover the specificity of how knowledge is generated in space and to provide deeper insight into 'what, when and how' geographical location influences innovative activities (Howells, 2002). In particular, this paper puts forward a simple claim that knowledge generation and its spatial configuration differ as the innovation process unfolds across time, which essentially adds to a more dynamic understanding of the geography of innovation. Including how innovative activities change location throughout the innovation process-for example, to the sites of suppliers or customers-corroborating that the innovation process is multilocational.

To the best of the author's knowledge, only a few studies have researched the spatial organization of innovation activities through a micro-level perspective on innovation processes (Davids \& Frenken, 2017; Gallaud \& Torre, 2004; Hermelin, Dahlström, \& Smas, 2014; Moodysson, 2008; Strambach, 2012). Although these studies all adopt a procedural approach, their findings show diverging results, which confirms the need for further 
examination. For example, Gallaud and Torre (2004) argue that the need for geographical proximity diminishes over time concurrently with increasing commercialized interactions. Conversely, Davids and Frenken (2017), Moodysson (2008) and Strambach (2012) support the idea that temporary geographical proximity is also needed, in some cases to an increased degree, at later developmental stages.

As an exploratory case study, this paper focuses on three innovation processes of Danish suppliers to the wind power industry located in Denmark and applies a biographical approach (Butzin \& Widmaier, 2016; Strambach \& Klement, 2012). By taking a processual approach to innovation, the case study confirms that spatial proximity is important throughout the innovation process but takes different forms.

The structure of the paper is as follows. Section two develops the analytical framework focusing on proximity dynamics in knowledge-creation processes as the innovation process unfolds over time. Section three introduces the empirical context and explains the methodological approach. Section four analyses the three innovation biographies. Section five discusses the key findings, and Section six draws up the conclusions.

\section{Theory and Background}

Innovation studies have been criticized for their tendency to focus rather narrowly on innovation as outputs, e.g., patents, products, and innovation statistics, and less on the actual process leading to innovation (Garud, Tuertscher, \& Van de Ven, 2013; Van de Ven, Polley, Garud, \& Venkataraman, 1999). This limitation reflects a failure to consider the long process of interactive knowledge generation, problem solving, testing, prototyping, etc. that occurs before any innovation reaches markets. Instead, the question of proximity is often treated as a matter of statistical (static) measures of spatial relationships. Consequently, the role of 
geographical proximity in innovation processes is often misrepresented, leading to a gap in the literature on the dynamic dimensions of how geographically proximate and distant knowledge sources vary over time throughout the innovation process. In particular, when innovative activities are stretched in space and may take place at multiple sites. To address this deficit, this paper is inspired by research such as the innovation journey (Van de Ven et al., 1999) and the innovation biography approach (Butzin \& Widmaier, 2016) that explicitly address the temporal sequence of activities in innovation processes.

\section{The Innovation Process and Proximity}

In essence, innovation processes are contingent by nature and differ by economic sector, technological field, type of innovation and knowledge bases, historical period and country concerned (Asheim \& Coenen, 2006; Asheim \& Gertler, 2005; Pavitt, 2005). Innovation processes are fluid processes that can be affected by many different types of firm-internal and firm-external factors. Creation of new knowledge is a vital component in innovation processes and occurs through interactive processes of (re-)combination and exchange (Nahapiet \& Ghoshal, 1998) facilitated through different types of proximity.

Geographical proximity is in this context perceived as one of several dimensions of proximity. Boschma (2005) identifies five dimensions—geographical, social, institutional, organizational and cognitive proximity_all of which influence interactive learning. Torre and Rallet (2005) introduce the concept of organized proximity as complementary to geographical proximity. Organized proximity (Torre, 2008) makes individuals capable of exchanging knowledge without being physically co-located through a 'logic of belonging' and a 'logic of similarity’. The logic of belonging is embedded in the social and institutional practices of a team or an organization (Nahapiet \& Ghoshal, 1998). It prescribes the behavioural rules (either explicitly or implicitly) that enable learning. The 'logic of similarity' is when two or more individuals are close to each other because they share same system of representation or 
similar knowledge bases_-in short, they are institutionally, cognitively and/or socially alike (Bouba-Olga, Carrincazeaux, Coris, \& Ferru, 2015).

Although organized proximity can facilitate learning over long distances (Torre \& Rallet, 2005), temporary geographical proximity is still important to facilitate knowledge exchange (Torre, 2008). Where Gallaud and Torre (2004) claim that temporary geographical proximity is mostly important in the beginning of innovation processes and that the need diminishes over time, empirical findings do not unambiguously support this claim. For instance, Davids and Frenken (2017) study how different knowledge bases and proximity logics play different roles at different stages in a single innovation project. They find that geographical proximity is low in early stages (Research) but higher at later stages (Development and Marketing). Likewise, Moodysson (2008) finds that, in the biotechnology industry in Sweden, the mode of knowledge creation (analytical vs. synthetic) and its spatial configuration shift between local and global. Similar to Davids and Frenken and in contrast to Gallaud and Torre (2004), both Moodyson (2008) and Strambach (2012) support that temporary geographical proximity is needed at later development stages and therefore does not diminish. Overall, these studies show diverging results for the importance of geographical proximity at different stages of the innovation process, which validate the aim of this paper.

\section{Innovation Processes and Knowledge Creation}

In the following, the key concepts of this paper are synthesized into an analytical framework explaining knowledge creation at the different stages of the innovation process; see Table 1. Although, there are different ways to characterize innovation processes (Garud et al., 2013; Pavitt, 2005; Utterback, 1971; Van de Ven et al., 1999), this study defines technological innovation processes rather simply in terms of having three overlapping steps or phases: idea generation, problem solving, and implementation (Garud et al., 2013; Utterback, 1971). This depiction does not involve a linear understanding of innovation; in reality, stages of the 
innovation process are difficult to distinguish from one another and are frequently

intertwined. Cognitively, innovation processes are opportunity driven and change between phases of understanding the problem and identifying and implementing solutions throughout the whole process (Conklin, 2006). Nevertheless, for analytical purposes, this paper adopts a 3-stage innovation process model covering idea generation, problem solving and implementation.

In all three stages of the innovation process (see Table 1), knowledge is characterized as complex, meaning that the knowledge involved in the innovative activities consists of a large number of parts that is related in a non-simple way (Kogut \& Zander, 1992; Simon, 1962). The complex knowledge goes through a process of being fuzzy in the idea generation phase, to be disconnected in the problem-solving phase to connected in a new product in the implementation stage. This 3-stage process is elaborated in the following.

Table 1: Knowledge creation and proximity dynamics during the stages of innovation

\begin{tabular}{|c|c|c|c|}
\hline & Idea generation & Problem-solving & Implementation \\
\hline $\begin{array}{l}\text { Knowledge } \\
\text { characteristics }\end{array}$ & $\begin{array}{l}\text { Knowledge is complex } \\
\text { and fuzzy } \\
\text { - Prior knowledge about } \\
\text { industry, markets, } \\
\text { customer problems and } \\
\text { how to serve customers } \\
\text { - Prior knowledge on } \\
\text { technology or solutions }\end{array}$ & $\begin{array}{l}\text { Knowledge is complex } \\
\text { and disconnected } \\
\text { - Combination and } \\
\text { exchange of tacit and } \\
\text { explicit knowledge } \\
\text { - Production of tacit } \\
\text { knowledge through } \\
\text { experimentation }\end{array}$ & $\begin{array}{l}\text { Knowledge is complex } \\
\text { but connected } \\
\text { - Codification of tacit } \\
\text { knowledge in } \\
\text { requirements } \\
\text { - Transfer of tacit } \\
\text { knowledge to suppliers, } \\
\text { producers and users }\end{array}$ \\
\hline Proximity & $\begin{array}{l}\text { Co-location in clusters } \\
\text { may be advantageous to } \\
\text { increase access to } \\
\text { industry-specific } \\
\text { knowledge } \\
\text { - Frequent temporary } \\
\text { face-to-face meetings at } \\
\text { customer sites, fairs etc. }\end{array}$ & $\begin{array}{l}\text { Early development } \\
\text { requires geo. proximity } \\
\text { (temporary or } \\
\text { permanent) } \\
\text { - } \text { Geo. proximity } \\
\text { diminishes concurrently } \\
\text { with increased org. } \\
\text { proximity }\end{array}$ & $\begin{array}{l}\text { Temporary geo. } \\
\text { proximity is important } \\
\text { to transfer knowledge to } \\
\text { external partners } \\
\text { - Organized proximity } \\
\text { can secure } \\
\text { communication } \\
\text { internally in the } \\
\text { organization through } \\
\text { knowledge enablers }\end{array}$ \\
\hline
\end{tabular}

The idea-generation phase is a rather messy process wherein no one fully understands the idea or emerging body of knowledge (Birkinshaw \& Sheehan, 2002). Very simply put, the idea-generation phase contains two elements: the identification of a need and matching the need to a means, such as a technical solution (Utterback, 1971). In the entrepreneurship literature, this process is labelled 'market opportunity identification' and is treated as the 
ability of individuals to recognize and develop opportunities. The process of market opportunity identification depends on the entrepreneurial alertness of individuals, which is constituted by three elements: personal traits, social networks and prior knowledge about markets, customer problems and how to serve customers (Ardichvili, Cardozo, \& Ray, 2003). It is widely agreed that the prior knowledge base of individuals will trigger recognition of the value of new knowledge (Shane, 2000) and hence, in the idea-generation phase, is extremely important to understand where there is a need for innovation.

The interesting question for this paper is what role geography plays in accessing industryspecific knowledge of the kind described above. On one hand it can be argued that access to industry specific knowledge may be increased by being localized in an industrial agglomeration since being located in a 'cluster' will more likely produce more frequent meetings between customers-suppliers, user-producers, etc. (Asheim \& Isaksen, 2002; Gertler, 1995). On the other hand, there is a widespread scepticism in the literature that colocation per se will increase access to the type of knowledge important for innovation (Boschma, 2005; Fitjar \& Rodríguez-Pose, 2011, 2017; Ibert \& Müller, 2015). In reality, meetings with partners are organised as temporary co-presence at the site of customers, through salespersons, in development projects or formally or informally at trade fairs or through established industrial networks like industry associations. Moreover access to industry-specific knowledge, which leads to identification of market opportunities, is not freely available for everyone located in a particular cluster. In contrast, it is very heterogeneously distributed among individuals and organizations (Giuliani, 2007) depending on who has 'invested' time and effort in good relationships with customers, collaborators, etc. Well-established individual networks give some representatives of an industry access to diverse knowledge resources for recombination (Vedres \& Stark, 2010), which is crucial to idea generation. Hence, it is through these individuals face-to-face meeting at customer's site, 
trade fairs, sales meetings etc. that increases certain individual's ability to identify opportunities that others do not see. Put together, co-location in clusters may be advantageous to increase access to industry-specific knowledge, because it may increase the frequency of meetings with partners, but the key point here is that access to industry-specific knowledge depends on individually developed networks not constituted by geographical proximity alone. Finally, identifying market opportunities also depends on the type of opportunity. Ardichvili et al. (2003) distinguish between four types of “opportunities" depending on whether the problem and/or solution are known or unknown. All the case studies in this paper fall within the category of 'problem-solving', which is a type of opportunities where the problem is known, but the solution is not.

The problem-solving phase extends from the moment the idea is proposed and initial resources have been allocated until the time at which a solution, model or prototype is completed. The sub-processes of the problem-solving phase involve identifying sub-problems, specifying technical requirements for solutions, evaluating and deciding on which solution to pursue. This stage involves high levels of interplay between tacit and explicit knowledge. Studies suggest that the tacit dimension is more profound in the problem-solving phase than in other stages of the innovation process (Koskinen \& Vanharanta, 2002), meaning highly intuitive and experience-based knowledge is used to identify sub-problems and work out solutions. Due to the complexity of such innovation projects, this task is often carried out by a team of co-workers who have different, complementary knowledge. Similarity in knowledge facilitates communication in identifying sub-problems and their solutions. When these solutions are tested through experimentation and modelling new knowledge is generated. Concurrently, problem solving also involves the codification of knowledge about requirement specifications to potential suppliers and producers (Kogut \& Zander, 1992). Hence, problem solving is characterized by individuals who use tacit experienced-based knowledge by 
themselves or in teams to identify sub-problems, develop solutions by combining and exchanging knowledge in new ways and test the new solutions. The latter is often experimental and involves the creation and accumulation of new tacit knowledge (Nonaka \& Takeuchi, 1995) in parallel with writing up explicit requirements that the product and its components must meet.

Consequently, in the problem-solving stage, it is necessary to create space for developing solutions (Birkinshaw \& Sheehan, 2002) and to facilitate the process of building a new concept based on new knowledge combinations and knowledge exchange. It involves high levels of tacit knowledge (previous experiences), which must be facilitated by either geographical or organized proximity. Moreover, at the very early stage of problem-solving, geographical proximity is needed whereas later it can be replaced by organized proximity (Torre, 2008), because organized proximity in itself is dynamic and co-evolves as the innovation process unfolds (Balland, Boschma, \& Frenken, 2015). In particular, the logic of similarity—a common knowledge base and associated vocabulary—may be lower in the beginning; hence, the level of geographical proximity (face-to-face interaction) needs to be higher.

Finally, implementation is related to manufacturing the solution and bringing the original idea to its first use or market introduction. Implementation considers manufacturing engineering, plant start-up, marketing, production, diffusion, on-going services, etc. This sub-process often involves close interplay with suppliers of components, producers of the entire product (if the product is not produced in-house) and the customers who will adopt the new product. For instance, Gertler (1995) shows that the production and adoption of new complex production equipment is more likely to be produced and/or adopted successfully when there is frequent interaction between producer and user and between producer and supplier. 
The tacit knowledge that has been accumulated based on experimentation in the problemsolving stage needs to be transferred to other parties, such as suppliers, producers and/or customers. Some of this knowledge is translated into explicit requirements; other knowledge is so complex that it is more easily facilitated by face-to-face interaction between the parties involved.

Firms and industries have developed different routines and strategies for the communication of tacit and codified knowledge at this stage of the innovation process. Large firms tend to develop knowledge management systems that seek to handle the transfer and exchange of tacit knowledge throughout the innovation process (Birkinshaw \& Sheehan, 2002), for example, systems to facilitate the codification of tacit knowledge or knowledge enablers who circulate tacit knowledge within the organization (Gertler, 2003; Von Krogh, Ichijō, \& Nonaka, 2000). Small and medium-sized firms have less-formalized support systems for this type of knowledge sharing (Koskinen \& Vanharanta, 2002). However, in small firms, the same people are often involved throughout the whole innovation process from idea generation to implementation, which secures continuity. It also lowers the need to transfer tacit knowledge internally in the organization because knowledge is embedded in the individual team members, who are involved in all stages of innovation.

As consequence, this may imply that there is no formalized practice of sharing tacit knowledge with external partners, such as suppliers or customers. Hence, it is theorized that these firms rely to a higher degree on knowledge enablers (Gertler, 2003; Von Krogh et al., 2000). That is, key personnel who can enable the dissemination of tacit knowledge with external partners and simultaneously retain the knowledge exchange and feedback to the rest of the team. The knowledge enabler needs to be geographically close to external partners at the site of the producer or customer, whereas knowledge sharing with the rest of the team members can be facilitated over longer distances due to organized proximity. 
In summary, despite the progress in understanding the geography of innovation, particularly the proximity dimensions' importance for knowledge creation, it is striking that the temporal dimension of innovation processes is lacking: How does the spatial configuration of knowledge creation change as the innovation process unfolds over time? In this section, it has been theoretically argued that geographical proximity plays a role in all stages of the innovation process, but its form varies. In identifying market opportunities, knowledge about customer problems and how to serve customers may be accessed easier through co-location in industrial agglomerations. In the problem-solving stage, face-to-face interaction is important but diminishes over time as organized proximity increases. In the implementation stage, where new actors (producers, suppliers, and customers) enter the core activities related to the innovation process, the importance of geographical proximity depends on innovative firms' knowledge management systems to transfer tacit knowledge. Where geographical proximity is important, it can be organized temporarily through knowledge enablers at different loci around the world. In consequence, leading to multilocational innovation processes.

\section{The Empirical Context and Methodological Approach}

The analytical framework proposed above is exemplified by a study of the wind power industry in Northern Europe, where the majority of development activities occur. The wind power industry developed in the 1970s after the oil crisis and has been characterized by rapid, complex technology development, high levels of uncertainty and changing business models to resist competition (Andersen \& Drejer, 2008; Awate, Larsen, \& Mudambi, 2014; Garud \& Karnoe, 2003).

In particular, two trends put pressure on the technology suppliers in wind and result in many innovative activities: the diversification of firms to the offshore sector and the rapid upgrading of wind turbine sizes. In the last 30 years, the size of the wind turbines have increased by a factor of 100 (Islam, Mekhilef, \& Saidur, 2013). 
The wind power industry in Denmark has sustained its significant position in the world, although the industry has experienced rapid globalization. Andersen and Drejer (2008) demonstrate how the organization of innovative activities has changed over the past four decades based on actors’ interests and motives for sharing knowledge. Innovative activities have developed from being characterized by collaborative openness in "small networks of like-minded and non-specialized collaborators” in the early years to being characterized by rapid globalization and investments by MNCs, resulting in "a centralized, systemic network, yet one with distributed knowledge” (Andersen \& Drejer, 2008, p. 41).

This study focuses on these types of distributed knowledge-creation processes expressed in the innovative activities of specialized suppliers to the wind power industry.

Although three types of interrelated industrial activities—sales, manufacturing and employment—have become increasingly internationalized, the wind power industry remains strongly anchored in Denmark and neighbouring countries (Sweden and Germany) mainly because of its long supply-side experience with wind turbine technology and the extensive research conducted at Danish universities and institutes (Danish Wind Industry, 2012; Hansen, Torp, \& Schaumburg-Müller, 2012).

\section{Research Method}

This study makes use of a biographical approach, which is characterized by its focus on the innovation process itself: the actors involved; the relationships between them; their knowledge contribution; and their geographical configuration (Strambach, 2012). Consequently, this study focuses not on a firm's intended procedure in general but on the product development activities and processes that occur within and beyond the boundaries of the firm. Interviews with those involved in the innovation process were conducted to uncover the actors involved, the knowledge relationships between them and their geographical configuration. 
The biographical approach has several advantages (Butzin \& Widmaier, 2016; Strambach, 2012). First, the biographical method can focus on distributed knowledge-generation activities and their evolution over time without being limited by a certain territorial scope or timeframe. Second, the method allows working with a flexible timespan because it aims to maintain its focus on how innovation processes unfold in time and space. Thus, by focusing on a single innovation process, this method enables the time-space paths of knowledge dynamics to be more flexibly reconstructed than other established data-gathering approaches.

Table 2 lists the three cases this study focuses on, including firm names and titles of interviewees. The interviews are balanced between the narrative of the project owner and a focus on the firm's context and its linkages to other partners in the innovation process. For each case, the aim was to interview the key people responsible and involved in the project, preferably the project owner and an R\&D a managing director. To assist in communicating the different stages of the innovation processes I brought a timeline printed on a large piece of paper, which both the interviewee and the interviewer used to visualize the process from idea to finished product. The timelines were used in drawing up the chronological sequence of the knowledge creation activities.

The interviews lasted between one to three hours and were conducted in combination with a field visit to the company's development site. The interview material and observations on the sites were complemented with primary and secondary data about customers, suppliers and the industry’s development in general, gathered by participating in industry specific conferences, reading industry newsletters, and meeting with industry associations. Finally, the interviews were followed up by shorter phone interviews and the interviewees had the transcribed interviews for approval and commenting. 
Table 2: Cases: Names of firms, innovative events, titles of interviewees and interview references

\begin{tabular}{|llll|}
\hline Innovation process & Firm (name, Danish town) & Interviewee & Reference \\
\hline $\begin{array}{l}\text { Fast-curing Polyurea } \\
\text { spartech, fast-curing paint } \\
\text { for wind turbine towers }\end{array}$ & Hempel, Lyngby & $\begin{array}{l}\text { Group Wind Power Segment } \\
\text { Manager }\end{array}$ & H1 \\
\cline { 2 - 4 } & & R\&D Director & H2 \\
\cline { 2 - 4 } $\begin{array}{l}\text { Blade Dragon, blade } \\
\text { installation crane }\end{array}$ & Liftra, Aalborg & Managing Director & L1 \\
\hline \begin{tabular}{llll|} 
Pacific Orca, windfarm \\
installation vessel
\end{tabular} & Swire Blue Ocean, Copenhagen & General Manager \& Director & S1 \\
\cline { 2 - 4 } & Knud E. Hansen, Helsingør & Senior Naval Architect & S2 \\
\hline
\end{tabular}

For the interviews with managing or R\&D directors, part of the interview was guided by questions about the firm's internal organization, established procedures for developing new products, sharing knowledge and other actions the firm may take to integrate external knowledge (e.g., hiring skilled staff, licensing patents, or creating strategic alliances).

The interviews were recorded, transcribed and coded following two approaches: an openended process following the issues the interviewee raised and a more structured approach that followed the phases of the innovation process, types of actors involved and knowledge types and flows. With respect to the different phases and sub-processes an innovation project passes through, each project has its own logic, which means that the sequence and length of the phases differ and that some phases might be repeated at later stages; hence, they were coded as development I and development II, for example.

\section{Innovation Biographies}

The innovations under scrutiny are characterized by being engineering-based and dominated by synthetic (Blade Dragon and Pacific Orca) and analytical (Fast-curing Polyurea) knowledge bases (Asheim \& Gertler, 2005). The innovation projects are presented in text boxes 1-3, and the knowledge-creation processes are analysed and compared in three sections on the different sub-processes of the innovation process. 


\section{Idea Generation}

The initial question for all innovation biographies is how the market opportunity is identified in the idea-generation phase. The stimulus for new ideas is inter-firm relationships with prospective customers, where individuals make use of access to diverse knowledge resources (Vedres \& Stark, 2010) through being embedded in social and industrial networks (Giuliani, 2007).

In the case of the Blade Dragon (see text box 1), the problem was formulated by a specific customer, a large wind turbine manufacturer facing challenges in installing wind turbines in a forest without clearing trees. The market opportunity was identified through frequent meetings with the customer about other projects, including visits to the customer's installation sites. In Liftra's innovation processes (L1, L2), the network relationships and diverse knowledge about the industry provides one of the managing partners with entrepreneurial alertness, which increases the likelihood of opportunities to be recognized (Ardichvili et al., 2003):

I am the one who has seen the most. (...) I have been offshore, and I have seen most turbine factories in Europe, for example, and in that way, seen and talked to customers and attended all the fairs and heard what problems they have now. I know what issues need to be solved. And then, I try and see if things can be done smarter ... It's not necessarily that they [customers] say, "Can you solve this problem?" But when I listen to them, I can hear that we can surely offer a smarter solution. ... When you look at how they do things today and you think that is a cumbersome way, can we do it in a smarter way? So it is about being out and seeing what happens and how they do things and then asking whether we can do it smarter. (L1: 202-212)

\section{Insert text box 1 around here}

Likewise, in the case of the Pacific Orca (see text box 2), entrepreneurial alertness played a major role in identification of the market opportunity. The main idea appeared based on informal talks between the managing director, who is a serial entrepreneur and experienced ship officer, and his cousin, who is an experienced engineer in wind turbine foundations for offshore sites. The latter had gained a thorough understanding of the industry and the gap in 
the value chain through working and engaging in the industry for many decades (S1). Together, they had prior knowledge about the industry, of customer problems and of ways to serve markets (Ardichvili et al., 2003), which increased the likelihood of successfully recognizing a market opportunity for a new installation vessel in the offshore wind sector (S1). Originally, the idea behind the Fast Curing Polyurea also derived based on close customer contacts, although from a different customer segment (see Text box 3). In some projects, the innovation process ceased if the customer lost interest, until a new customer (market opportunity) was found or developed (L1, L2, H3).

In sum, knowledge about current directions in markets and technology development as well as knowledge about customers and how to serve them was key to identify new market opportunities. Characteristic for the idea generation stage is that some individuals, in terms of Vedres and Stark’s (2010) terminology, have access to diverse resources, such as customer or regulatory logics, which stimulate the generation of new ideas.

\section{Insert Text box 2 around here}

Consequently, as opposed to the biotechnology industry, where Moodysson (2008) finds that brainstorming activities are the common way of generating new ideas, or to Davids and Frenken’s study (2017), where market opportunity is identified through scientific progress, in the engineering-based wind power industry, market-opportunities are identified based on personal experiences and traits, knowledge about the industry and the existence and access to the logics of prospective customers. 


\section{Problem Solving}

Initially, the problem-solving stages commence with a thinking period allowing developers to delve into the overall concept (L2, H3). When the concept begins to take shape, more resources are allocated to the project (S2, H2, H3, L2).

The knowledge-creation activities can be divided into two types: core innovative activities and scanning the state-of-the-art. The core innovative activities occur either internally in the focal firm (Liftra and Hempel) or at the site of the key sub-supplier (Knud E. Hansen). In particular, at the early stage, face-to-face interaction is crucial because problem-solving activities build on high degrees of tacit knowledge. This confirms von Hippel’s (1994) findings that problem-solving activities occur where the "sticky" information needed to develop the solutions exists. In the case of developing the installation vessel, the Pacific Orca, sticky information was located at the site of the naval architecture firm; hence, the core innovative activities occurred there with frequent meetings with the project initiator, Swire Blue Ocean, to specify the requirements of the design (S2, S1). The need to be geographically proximate (permanent or temporary) in the problem-solving stage is in line with previous research (Amin \& Cohendet, 2000; Davids \& Frenken, 2017; Moodysson, 2008; Strambach, 2012)

The core innovative activities were carried out by a team of engineers assigned to work on the design and early drawings. Common among these cases was that each team member was responsible for different sub-problems, demonstrating the complexity of the innovation project. Based on each team member’s individually accrued knowledge bases, the teams were able to combine and exchange their knowledge to address each sub-problem and the complex interplay between them (S2, L1, L2, H3).

The team of engineers provided the source of the production of new knowledge (tacit and explicit) in relation to developing, testing, validating and coordinating solutions for each subtask. In line with Gertler (2003), the team was able to produce new knowledge in this part of 
the innovation process by experiencing how things would work out in practice. Such as, when the Liftra team tested different materials to be used when lifting the wind turbine blades to the rotor (see Text box 1), they gained hands-on experience with the material, which was crucial knowledge for the innovation project. This is distinctive of the synthetic mode of knowledge creation that characterizes engineering practices (Moodysson, 2008), where it is not necessarily important to know why systems work in a specific way, as long as you know how they work.

The second type of knowledge-related activity is the search for specific knowledge input from customers, competitors and/or (potential) suppliers. Initial work is concentrated on discovering the state-of-the-art, as illustrated by the following quote by one of the key engineers working on the Pacific Orca at the naval architecture firm:

Of course, there is also the fact that you are looking at what competitors are doing, and you compare what is available on the market. What types of platforms are available? How are they constructed? What type of legs do they use? That's what we call 'competitor research', right? And that is in a very early design stage that you want to find out what is really state-of-the-art in the market in this area at that particular time (S2, 1:303-307).

The two types of knowledge-related activities confirm the findings of Moodysson (2008), who shows how the search for new knowledge in the problem-solving phase in the biotechnology sector is characterized by globally distributed networks (communities of practice), whereas the knowledge-creation activities in the design and prototyping parts are based on more local knowledge-interaction activities. Similarly, I find that the initial broad search for state-of-the-art solutions based on monitoring and researching competitors and suppliers is performed using the Internet and direct requests to suppliers on their product specifications (S2, H3, L2), where proximity is not important. For example, specific requirements to the yoke depended on the specific dimensions of the wind turbine blades, which was information given by the customer. Or in the case of the Pacific Orca as illustrated 
in the quote above on 'competitor research' and in Text box 2, on the complex interplay between the different components on the vessel (crane, legs, jack-up system etc.). However, the testing, validation and evaluation of different solutions and decisions about which solution to pursue required geographical proximity.

\section{Implementation}

Once a prototype or design is developed, the innovative activities are concerned with transforming this knowledge into working artefacts. Hence, many problem-solving activities occur in the implementation stage but are centred on applying the developed concept. In all three projects, the level of tacit knowledge on the interdependencies between components in the developed concept is high at this stage (H2, L2, S2). This knowledge is experience-based and accumulated through the testing and validation of subtasks carried out in the problemsolving stage. The challenge in the implementation stage is to convert this knowledge into a functional product.

In the case of the Blade Dragon and the Pacific Orca, construction occurred at the site of suppliers, whereas in the case of the Fast-curing Polyurea (see text box 3), the paint was produced in-house. Nevertheless, the salient aspect of the innovative success of the Fastcuring Polyurea was the application process at the customer's site. Hence, the fast-curing polyurea was first applied manually at a prototype tower at one site in Denmark (Esbjerg) before the implementation process was moved to the customer's production line at another site in Denmark (Nyborg), where the application process was automated.

\section{Insert Text box 3 around here}

The knowledge transfer to manufacturers and customers followed two approaches: either by stationing key knowledge workers at the site of the supplier and/or customer or by codifying the tacit knowledge into detailed specifications and drawings. 
The Fast-curing Polyurea and Blade Dragon projects followed the former approach. Because of the high degree of tacit knowledge involved in the implementation stage, one or more employees had to be present throughout the whole development stage, adjust the concept, align goals and exchange knowledge between the supplier and/or customers and the engineering team in the home organizations (H2, L2). As such, these individuals became knowledge enablers (Gertler, 2003; Von Krogh et al., 2000) between the supplier/customer and the home organization and were able to maintain the knowledge flow and continuous learning 'at home', while having the main responsibility for implementing the product. Despite the complexity of knowledge at this stage, these individuals secured learning at the site and in the home organization because of organized proximity (Torre \& Rallet, 2005). Nevertheless, the development of a prototype and fine-tuning of the product required temporary geographical proximity (Torre, 2008) with the supplier or customer on a daily basis, hence the stationing of key knowledge workers.

The R\&D manager of the Fast-curing Polyurea project explained why they had stationed both technicians and chemical engineers at the customer's production facility for the months it took to implement the new production line.

First, we have some technicians we call coating advisors, who are out there on the spot to help. Second, we have our chemists, who have developed the product, on the site as well. When it is a new production line like this one, then the chemists are also there to see what is going on. So it's like a collaboration between people who are experienced in being at workplaces where you apply paint, they can see something, and then, our chemists can see something else because they know what is in the paint, so they know what to adjust to improve the product (H2: 1223-229).

Key to this approach is allowing the individuals who were responsible for the problemsolving tasks to be involved in the implementation stage and to secure mutual knowledge transfer between different partners. Knowledge was thus embedded in the individual project worker and transferred in temporary geographical proximity at specific work sites. 
In contrast, in the shipbuilding industry, the handling of and handing over of knowledge generated in the problem-solving phase are more systematized. There are standardized ways of codifying tacit knowledge in detailed explicit drawings, requirements and makers lists, which can be handed over to the shipyard. Another specific practice developed in shipbuilding that requires systematized knowledge transfer processes is the role played by classification companies. Before the shipyard takes on the drawings, they must be approved by a classification company, and they must again be approved when the shipyard has made the detailed production drawings (S2 1: 445-452). Consequently, this case differs from the other cases regarding the transfer of knowledge produced in the problem-solving phase, by having formalized systems and structures that require and support the codification of knowledge.

\section{Discussion}

The analysis of the three innovation processes exemplify different spatial and temporal patterns of knowledge interactions between project owners, customers and suppliers throughout the innovation processes. Qualitative studies of micro processes gives the opportunity to go beyond generalized perceptions of spatial dynamics of innovation and contribute to a deeper understanding of when and how geographical location influences innovative activities. This section discusses two key findings related to the geography of the firm, namely the mobility of innovation-related activities and the question of the firm's location in an industrial agglomeration.

The most obvious finding (yet important for our understanding of localized learning) is that, in all three cases, the main level of innovation activities changed location at least once during the innovation process. With respect to Pacific Orca, the main level of innovation activities changed site from the location of the project owner to the site of the key supplier (the naval architecture firm) in the problem-solving phase and again to the shipyard in the 
implementation phase. With respect to both the Blade Dragon and the Fast-curing Polyurea, the main innovation activities changed location in the implementation phase. In the former case, the site changed twice: first to the construction site of the supplier in Poland and then to the customer's site in northern Germany. In the Fast-curing Polyurea, the location of the main innovation activities changed to developing the automated application process at the customer's site. Thus, geographical proximity-understood as face-to-face meetings between individuals — is organised temporarily and is not limited to the location of the firm. Consequently, this study indicates not only that, as the innovation process unfolds over time, it involves different types of actors but also that the core level of innovation activities relocate to physical sites that may be geographically distant from the source of knowledge production. This corroborates that the need for geographical proximity does not diminish over time. This finding also confirms other literature, which demonstrate that it is important for firms' innovativeness that they are capable of approaching and acquiring knowledge from geographically distant locations (Bramwell, Nelles, \& Wolfe, 2008; Fitjar \& Rodríguez-Pose, 2011; Gertler \& Levitte, 2005; Niosi \& Zhegu, 2005; Simmie, 2003; Tödtling, Grillitsch, \& Höglinger, 2012; Tödtling, Lehner, \& Trippl, 2006). It also extends this work by providing a richer understanding of how the innovation process is flexible in its geographical configuration and can be perceived as multilocational because of the mobility of innovationrelated activities. It hence alters the conceptualization of 'localized learning processes' because, when the innovative activities relocate to different regions, the localized context shift correspondingly.

This understanding of firms relocating innovative activities to different regions, countries or continents and still being capable of transferring and sharing tacit knowledge is important to bear in mind when analysing how firms approach and acquire international knowledge in the innovation process. Hence, the static type of knowledge provided by some research that firms 
rely on international knowledge sourcing in the innovation process tells us little about how, where or when a firm approaches and acquires such knowledge (see also Ibert and Müller, 2015).

Finally, another debate the finding relates to is whether firms' location in an industrial agglomeration is important for the innovation process. The results indicate that the early stages of idea generation or identifying market opportunities is driven by individuals’ access to diverse knowledge resources through their networks to industry actors. Whether a firm's location ease the access to diverse knowledge resources is still under-investigated and the three innovation processes studied in this paper does not clearly support this claim. If being co-located in a cluster ease access to industry-specific knowledge by lowering transaction costs and increasing levels of trust it is still an open question, whether this knowledge flow can be directly linked to the process of idea generation.

Nonetheless, the locality of the firms seems to be less relevant at later phases of the innovation process, where firms must be more flexible in how their knowledge work is organized and, in fact, must be capable of operating in different locations throughout the innovation process.

\section{Conclusion}

This paper adopted a micro-process perspective to develop a better understanding of how local and non-local knowledge sources vary throughout the innovation process. By applying a biographical approach (Butzin \& Widmaier, 2016), the paper followed knowledge creation in three innovation processes as they unfolded over time and across space. The key insights from the exploratory case study centres on two aspects: 1) how spatiotemporal patterns of knowledge interactions vary throughout the innovation process, and 2) how the core level of innovative activities changes physical location during the innovation process, 
The first insight confirms previous findings that geographical proximity is important throughout the innovation process but that its configuration changes between face-to-face interaction in permanent and temporary geographical proximity, depending on the type of knowledge-creation activities. The second insight suggests that innovation processes are stretched in space and may take place at multiple sites. Consequently, being able to operate at multiple locations is also relevant for firms that are not spatially differentiated organizations by nature, such as multinational corporations.

Moreover, this study confirms that prior knowledge about the industry, markets, customer problems, etc. is important for generating new ideas and developing and identifying market opportunities (Ardichvili et al., 2003). Although such knowledge is denser in some geographical areas (e.g., in clusters), it was argued that access to diverse knowledge resources (Vedres \& Stark, 2010) is heterogeneously distributed among actors in clusters (Giuliani, 2007). Since meetings may be easier organised when located in geographical proximity, the study indicates that the firm's location may affect how easily industry-specific knowledge can be accessed. However, this hypothesis needs further investigation before we can link the benefit of clusters directly to the identification of market opportunities.

In sum, taking seriously the temporal dimension of proximities in innovation processes leads to asking new research questions, which potentially can add to the understanding of why, when and how industrial agglomerations matter in innovation processes. In particular, as this study proposes, that the location of the firm and being located close to wind power markets may primarily be important in the early stages of the innovation process.

This paper's conclusions are, of course, limited in terms of generalization because it builds only on three innovation processes in the engineering-based wind power industry. A natural question arises regarding whether these findings are equally valid for other industries or technologies or unique to the wind power industry, which is characterized by very large-scale 
innovations. Further studies must decide whether similar patterns of knowledge interactions are present in other industries or for other innovation projects that differs from the problemsolving type (Ardichvili et al., 2003).

Second, the analysis is also restricted because it draws on a limited number of interviews. Although previous research (Balland, Suire, \& Vicente, 2013) supports this finding, it would be of great interest to test these results with larger, more generalizable data sources. In particular, examining whether the local level of knowledge interactions is more important in phases involving the generation of new ideas and developing market opportunities than in later phases of the innovation process. Such studies would add great academic value to the literature on the geography of innovation if they could generally support that different geographical levels have varied significance throughout the innovation process.

Finally, such studies could also add legitimacy and quality to designing innovation policy that supports companies working across regional and national borders. Much policy, particularly regional innovation policy, has been preoccupied with creating and supporting cluster dynamics by building up local networks between companies. However as Schmidt et al (2018) propose, regional innovation policy should go beyond the logic of territorial innovation models and promote innovation processes, which are inherently mobile and multilocal. For example, by supporting the build-up of extra-regional and international knowledge networks or improving framework conditions for the support of different types of knowledgesharing mechanisms, such as labour mobility and strategic alliances. If further studies can confirm the temporal aspects and variations of proximities in knowledge creation throughout the innovation process, such policies may be designed to have a much stronger impact.

Acknowledgement: This research received financial support through EIS - Strategic research alliance for Energy Innovation Systems and their dynamics. EIS is funded by the Danish 
Council for Strategic Research, the Programme Commission on Sustainable Energy and

Environment, and by the participating research institutions.

\section{References}

Amin, A., \& Cohendet, P. (2000). Organisational Learning and Governance Through Embedded Practices. Journal of Management and Governance, 4(1/2), 93-116.

Andersen, P. H., \& Drejer, I. (2008). Systemic innovation in a distributed network: The case of Danish wind turbines, 1972-2007. Strategic Organization, 6(6), 13-46.

Ardichvili, A., Cardozo, R., \& Ray, S. (2003). A theory of entrepreneurial opportunity identification and development. Journal of Business Venturing, 18(1), 105-123.

Asheim, B., \& Coenen, L. (2006). Contextualising regional innovation systems in a globalising learning economy: On knowledge bases and institutional frameworks. The Journal of Technology Transfer, 31(1), 163-173.

Asheim, B., \& Gertler, M. S. (2005). The geography of innovation: regional innovation systems. In J. Fagerberg, D. C. Mowery, \& R. R. Nelson (Eds.), The Oxford handbook of innovation (pp. 291-317). Oxford university press.

Asheim, B., \& Isaksen, A. (2002). Regional Innovation Systems: The Integration of Local "Sticky" and Global "Ubiquitous” Knowledge. Journal of Technology Transfer, 27(1), 77-86.

Awate, S., Larsen, M. M., \& Mudambi, R. (2014). Accessing vs sourcing knowledge: A comparative study of R\&D internationalization between emerging and advanced economy firms. Journal of International Business Studies, 46(1), 63-86.

Balland, P.-A., Boschma, R., \& Frenken, K. (2015). Proximity and Innovation: From Statics to Dynamics. Regional Studies, 49(6), 907-920.

Balland, P.-A., Suire, R., \& Vicente, J. (2013). Structural and geographical patterns of knowledge networks in emerging technological standards: Evidence from the European GNSS industry. Economics of Innovation and New Technology, 22(1), 47-72.

Birkinshaw, J., \& Sheehan, T. (2002). Managing the knowledge life cycle. MIT Sloan Management Review, 44(1), 75-83.

Boschma, R. (2005). Proximity and Innovation: A Critical Assessment. Regional Studies, 39(1), 61-74.

Bouba-Olga, O., Carrincazeaux, C., Coris, M., \& Ferru, M. (2015). Proximity Dynamics, Social Networks and Innovation. Regional Studies, 49(6), 901-906.

Bramwell, A., Nelles, J., \& Wolfe, D. a. (2008). Knowledge, Innovation and Institutions: Global and Local Dimensions of the ICT Cluster in Waterloo, Canada. Regional Studies, 42(1), 101-116.

Butzin, A., \& Widmaier, B. (2016). Exploring Territorial Knowledge Dynamics through Innovation Biographies. Regional Studies, 50(2), 220-232.

Conklin, J. (2006). Wicked Problems and Social Complexity. In Dialogue Mapping: Building Shared Understanding of Wicked Problems (pp. 3-40). West Sussex: John Wiley \& 
Sons, Ltd.

Danish Wind Industry. (2012). Denmark - the wind power hub; transforming the supply chain. Copenhagen, Denmark.

Davids, M., \& Frenken, K. (2017). Proximity, knowledge base and the innovation process: towards an integrated framework. Regional Studies, 1-12.

Fitjar, R. D., \& Rodríguez-Pose, A. (2011). When local interaction does not suffice: Sources of firm innovation in urban Norway. Environment and Planning A, 43(6), 1248-1267.

Fitjar, R. D., \& Rodríguez-Pose, A. (2017). Nothing is in the Air. Growth and Change, 48(1), 22-39.

Gallaud, D., \& Torre, A. (2004). Geographical proximity and the diffusion of knowledge (the case of SMEs in biotechnology). In G. Fuchs, P. Shapira, \& A. Koch (Eds.), Rethinking Regional Innovation and Change. Economics of Science, Technology and Innovation (pp. 127-146). New York: Springer.

Garud, R., \& Karnoe, P. (2003). Bricolage vs. breakthrough: distributed and embedded ageny in technology entrepreneurship. Research Policy, 32(2), 277-300.

Garud, R., Tuertscher, P., \& Van de Ven, A. H. (2013). Perspectives on Innovation Processes. The Academy of Management Annals, 7(1), 775-819.

Gertler, M. S. (1995). “ Being There”: Proximity, Organization, and Culture in the Development and Adoption of Advanced Manufacturing Technologies. Economic Geography, 71(1), 1-26. Retrieved from http://www.jstor.org/stable/10.2307/144433

Gertler, M. S. (2003). Tacit knowledge and the economic geography of context, or The undefinable tacitness of being (there). Journal of Economic Geography, 3(1), 75-99.

Gertler, M. S., \& Levitte, Y. M. (2005). Local Nodes in Global Networks: The Geography of Knowledge Flows in Biotechnology Innovation. Industry \& Innovation, 12(4), 487-507.

Giuliani, E. (2007). The selective nature of knowledge networks in clusters: evidence from the wine industry. Journal of Economic Geography, 7(2), 139-168.

Hansen, M. W., Torp, J. E., \& Schaumburg-Müller, H. (2012). What Explains Asian Investments in Denmark? In M. Marinov \& S. Marinova (Eds.), Internationalization of Emerging Economies and Firms (pp. 343-366). Palgrave Macmillan.

Hermelin, B., Dahlström, M., \& Smas, L. (2014). Geographies of knowledge and learning: The example of medical technology. Growth and Change, 45(3), 450-470.

Howells, J. R. L. (2002). Tacit knowledge, innovation and economic geography. Urban Studies, 39(5-6), 871-884.

Ibert, O., Hautala, J., \& Jauhiainen, J. S. (2015). From cluster to process: New economic geographic perspectives on practices of knowledge creation. Geoforum, 65, 323-327.

Ibert, O., \& Müller, F. C. (2015). Network dynamics in constellations of cultural differences: Relational distance in innovation processes in legal services and biotechnology. Research Policy, 44(1), 181-194.

Islam, M. R., Mekhilef, S., \& Saidur, R. (2013). Progress and recent trends of wind energy technology. Renewable and Sustainable Energy Reviews, 21, 456-468.

Kogut, B., \& Zander, U. (1992). Knowledge of the firm, combinative capabilities, and the replication of technology. Organization Science, 383-397.

Koskinen, K. U., \& Vanharanta, H. (2002). The role of tacit knowledge in innovation 
processes of small technology companies. International Journal of Production Economics, 80(1), 57-64.

Maskell, P., \& Malmberg, A. (1999). Localised learning and industrial competitiveness. Cambridge Journal of Economics, 23(2), 167-185.

Moodysson, J. (2008). Principles and practices of knowledge creation: On the organization of "buzz" and "pipelines” in life science communities. Economic Geography, 84(4), 449469.

Nahapiet, J., \& Ghoshal, S. (1998). Social Capital, Intecllectual Capital, and the Organizational Advantage. Academy of Management Review, 23(2), 242-266.

Niosi, J., \& Zhegu, M. (2005). Aerospace clusters: Local or global knowledge spillovers? Industry and Innovation, 12(1), 5-29.

Nonaka, I., \& Takeuchi, H. (1995). The Knowledge-Creating Company: How Japanese Companies Create the Dynamics of Innovation. Oxford University Press New York.

Pavitt, K. (2005). Innovation Processes. In Oxford Handbook of Innovation, Oxford University Press, Oxford. Oxford University Press.

Porter, M. E. (1990). The Competitive Advantage of Nations. New York: The Free Press.

Rusten, G., \& Overå, R. (2014). Local and global geographies of innovation: Structures, processes, and geographical contexts from a firm perspective. Growth and Change, 45(3), 403-411.

Schmidt, S., Müller, F. C., Ibert, O., \& Brinks, V. (2018). Open Region: Creating and exploiting opportunities for innovation at the regional scale. European Urban and Regional Studies, 25(2), 187-205.

Shane, S. (2000). Prior Knowledge and the Discovery of Entrepreneurial Opportunities. Organization Science, 11(4), 448-469.

Simmie, J. (2003). Innovation and Urban Regions as National and International Nodes for the Transfer and Sharing of Knowledge. Regional Studies, 37(6-7), 607-620.

Simon, H. (1962). The Architecture of Complexity. Proceedings of the American Philosophical Society, 106, 467-482.

Strambach, S. (2012). Knowledge Dynamics and Knowledge Commodification of KIBS in Time and Space. In E. Di Di Maria, R. Grandinetti, \& B. Di Bernardo (Eds.), Exploring Knowledge-Intensive Business Services: Knowledge Management Strategies (pp. 56-78). Hampshire, UK: Palgrave Macmillan.

Strambach, S., \& Klement, B. (2012). Cumulative and Combinatorial Micro-dynamics of Knowledge: The Role of Space and Place in Knowledge Integration. European Planning Studies, 20(11), 1843-1866.

Tödtling, F., Grillitsch, M., \& Höglinger, C. (2012). Knowledge Sourcing and Innovation in Austrian ICT Companies-How Does Geography Matter? Industry \& Innovation, 19(4), 327-348.

Tödtling, F., Lehner, P., \& Trippl, M. (2006). Innovation in knowledge intensive industries: The nature and geography of knowledge links. European Planning Studies, 14(8), 10351058.

Torre, A. (2008). On the Role Played by Temporary Geographical Proximity in Knowledge Transmission. Regional Studies, 42(6), 869-889.

Torre, A., \& Rallet, A. (2005). Proximity and Localization. Regional Studies, 39(1), 47-59. 
Utterback, J. M. (1971). The Process of Innovation: A study of the origination and development of ideas for new scientific instruments. IEEE - Transactions on Engineering Management, EM-18(4), 124-131.

Van de Ven, A. H., Polley, D., Garud, R., \& Venkataraman, S. (1999). The Innovation Journey.

Vedres, B., \& Stark, D. (2010). Structural Folds: Generative Disruption in Overlapping Groups. American Journal of Sociology, 115(4), 1150-1190.

von Hippel, E. (1994). “Sticky Information” and the Locus of Problem Solving: Implications for Innovation. Management Science, 40(4), 429-439.

Von Krogh, G., Ichijō, K., \& Nonaka, I. (2000). Enabling knowledge creation : how to unlock the mystery of tacit knowledge and release the power of innovation. Oxford University Press. 
The Blade Dragon is a yoke that enables the installation of blades on rotors at most angles, which can function in wind up to $12 \mathrm{~m} / \mathrm{s}$. The yoke can tilt a blade from $+30 \mathrm{deg}$. to $-5 \mathrm{deg}$. and can be used on land and offshore. Liftra A/S initiated this project in 2009 and finished in the summer of 2012. One sub-task of the project was to identify a material that could be used to protect the surface of the wind turbine blade when lifting it to the rotor and that simultaneously provided a high level of frictional resistance against the smooth surface of the blade (L2: 131-143). In their search, they were in contact with suppliers (in many different locations) of such materials to acquire data on frictional resistance. However, because no supplier could provide sufficiently reliable data on their materials to prove its function, the team conducted their own tests.

Throughout the idea-generation and problem-solving stages, the core innovative activities were located at the site of the focal firm, Liftra, and carried out by a team of engineers. In the implementation stage, the innovative activities shifted location to, first, the site of a steel supplier in Poland and, second, to the customer's site in Germany. At these sites, key knowledge workers from Liftra were stationed for periods of 3-6 months to keep developing and adjusting the design. 
The Pacific Orca is an offshore construction jack-up for the installation of wind turbines at sea. Safety is enhanced through a 6-leg design that allows the vessel to remain safely standing in the event of a sea bed "punch through" during operations. With a large cargo area and high-capacity deck loading, it can load 12 3.6-MW wind turbines. The innovation project was initiated by the small start-up Blue Ocean Ships A/S, which was acquired by a multinational conglomerate, Swire Group, during the innovation process.

The initial idea was to build a vessel that could operate in water depths of 25-30 meters; however, during the four-year-long development project, the specifications from the customer were repeatedly up-scaled to meet changes in market development. Currently, the vessel can operate in water depths up to $60 \mathrm{~m}$. The challenges related to continuously upscaling demonstrate the installation vessel's systemic character; it requires coordinating and weighing every choice against the consequences for overall price, safety and usability. Operating in such deep water requires truss legs (rather than standard plate legs) because these are lighter and can resist higher levels of wave impact. However, the choice of truss legs had consequences for the type and price of the jacking system and main crane. To provide a safe loading space on the deck, the crane was constructed around one of the legs, and because truss legs have a wider diameter than plate legs, it placed additional requirements on the crane's suppliers.

Already at the problem-solving stage, the core innovative activities moved to the site of the key supplier, namely, an experienced Danish naval architecture company (Knud E. Hansen), which played a key role as the main provider of technical knowledge and engineering solutions. Through a period of four years, the two partners had frequent meetings where requirements and solutions were developed. The meetings required faceto-face contact because of the high level of complexity and tacit knowledge in the design and sizing of the vessel (S2: 274-282). In the implementation stage, the development moved to the shipyard of Samsung Heavy Industries in Korea. The tacit knowledge derived in the problem-solving stage was formalized and codified in detailed drawings and specifications for the vessel. 


\section{Text box 3: Fast-curing polyurea, Hempel A/S}

Fast-curing Polyurea is a fast-curing paint that can be applied in one coat directly to metal and touched within one hour. The project focused on making a one-coat, direct-tometal product to be applied on a new type of line-produced wind turbine towers.

The main idea behind a fast-curing paint derived from one of Hempel's other business segments (Industry) more than a decade ago. The project was never realized but lived a quiet life as a "garage-project": R\&D employees worked on it when regular projects did not need their full attention. In these early days, the project was never realized because the key ingredient was protected by a patent, and the production cost was thus excessively high. When the current project was initiated, the patent was set to expire; consequently, it was worth negotiating the price, which improved the economics of the project significantly.

Continuous internal testing of the required level of corrosion protection and curing was a crucial part of the problem-solving phase. Through tests and practical experimentations new knowledge was created. To ensure the firm could deliver, most of the problem-solving occurred internally before negotiations with the customer began. The Fast-curing Polyurea was first applied manually at a prototype tower at one site in Denmark (Esbjerg) before the implementation process was moved to the customer's production line at another site in Denmark (Nyborg), where the challenge was to automate the application process. During the implementation, Hempel relocated innovation activities by stationing several employees at the site of the customer to share high levels of tacit knowledge. Knowledge was likewise transferred "home" to adjust the chemical constituents of the paint. 